\title{
HYBRID COURT SEBAGAI ALTERNATIF PENYELESAIAN PELANGGARAN HAK ASASI MANUSIA
}

\author{
Cholidah \\ Fakultas Hukum Universitas Muhammadiyah Malang \\ Jl. Raya Tlogomas No. 246 Malang \\ E-mail : cholidahbaghos@gmail.com
}

\begin{abstract}
The establishment of the International Criminal Court (ICC) in 1998 provided a hope for certainty in resolving cases of international human rights crimes that occurred after the Rome Statute which formed the basis of this court ratification in 1998, the Non-Retroactive Principles adopted in the Rome Statute did not open this courtroom Human rights crimes that occurred before 1998, so that a new court model is needed to resolve human rights cases that occur namely the Hybrid Court Judicial model, also known as the Mixed Court model, seeks to combine national legal and judicial elements with the International. This Alternative Model is then chosen in resolving cases of human rights crimes that occurred in Sierra Leone and Cambodia, but given the different human rights crimes that occur, different approaches and models are needed in the formation of selected Hybrid Court Courts. So it needs to be explored about the urgency, the legal status of Hybrid Court formation, as well as the technical mechanisms of the trial, both Special Court for Sierra Leone and Extra Chamber Court of Cambodian/ECCC. The results of this study are first, the urgency of the formation of Hybrid Court is to fill the limitations of temporis jurisdiction from the ICC as an institution in prosecuting perpetrators of international crimes so as to close the impunity of perpetrators because the State can still try its citizens by using its domestic legal system without having to fully use the International mechanism. Second, Hybrid Court can be formed through agreements between the United Nations and the government of a country which is then used as a legal basis for the court, as implemented in Cambodia, besides that the formation of Hybrid Court can also be formed through national laws as applied in Sierra Leone.
\end{abstract}

Keywords : Hybrid Court, Alternative, Human Right Violation

\begin{abstract}
Abstrak
Pembentukan Mahkamah Pidana Internasional (ICC) pada tahun 1998 memberikan suatu harapan akan kepastian penyelesaian kasus kejahatan HAM Internasional yang terjadi setelah Statuta Roma yang menjadi dasar pembentukan pengadilan ini disahkan pada tahun 1998, Asas Non Retroaktif yang dianut dalam Statuta Roma tidak membuka ruang pengadilan ini mengadili kejahatan HAM yang terjadi sebelum tahun 1998 sehingga di perlukan model paradilan baru guna menyelesaikan kasus- kasus HAM yang terjadi yakni model Peradilan Hybrid Court atau dikenal sebagai Mixed Court model peradilan ini berusaha mengkombinasikan elemen-elemen hukum dan peradilan nasional dengan Internasional.
\end{abstract}


Model Alternatif inilah yang kemudian dipilih dalam menyelesaikan kasus kejahatan HAM yang terjadi di Sierra Leone dan Kamboja, namun mengingat kejahatan HAM yang terjadi berbeda maka diperlukan pendekatan dan model yang berbeda dalam pembentukan Peradilan Hybrid Court yang dipilih. Sehingga perlu digali tentang bagaimana urgensi, status hukum pembentukan Hybrid Court, serta mekanisme teknis peradilannya baik Special Court For Sierra Leone maupun Extra Chamber Court of Cambodian/ECCC. Adapun hasil dari penelitian ini adalah pertama, urgensi pembentukan Hybrid Court adalah mengisi keterbatasan jurisdiction temporis dari ICC sebagai institusi dalam mengadili pelaku kejahatan Internasional sehingga menutup ruang terjadinya impunitas pelaku karena Negara tetap dapat mengadili warga negaranya dengan memakai sistem hukum domestiknya tanpa harus sepenuhnya menggunakan mekanisme Internasional. Kedua, Hybrid Court dapat dibentuk melalui perjanjian antara PBB dengan pemerintah suatu negara yang kemudian dijadikan landasan hukum pada pengadilan, seperti yang terapkan di Kamboja, selain itu pembentukan Hybrid Court dapat pula terbentuk melalui undang-undang nasional seperti yang terapkan di Sierra Leone.

\section{Kata Kunci : Hybrid Court, Alternatif, Pelanggaran HAM}

\section{A. PENDAHULUAN}

Sejarah dunia mencatat tidak ada suatu negara manapun yang tidak pernah terlibat konflik dalam perang, baik itu konflik internal dalam negeri maupun konflik bersenjata Internasional karena perang itu merupakan tingkah laku sosial suatu bangsa dalam mencapai tujuan-tujuan geopolitiknya, dan yang lebih jauh lagi bahwa perang sesungguhnya suatu bentuk tingkah laku yang hanya dapat ditemukan di dalam lingkungan manusia yang mengenal kehidupan bernegara. ${ }^{1}$

Korban jiwa manusia dan juga kerusakan yang besar terhadap objek-objek budaya warisan budaya bagi seluruh umat manusia merupakan Konsekuensi logis dari sebuah Sengketa bersenjata internasional ${ }^{2}$. sebagaimana tercatat didalam Perang Dunia I tidak kurang dari 40.000.000 orang menjadi korban perang, dan dalam Perang Dunia II jumlahnya berkisar pada angka 60.000 .000 orang. $^{3}$

Setiap peperangan yang terjadi sangat dimungkinkan terjadi pelanggaran terhadap hukum Humaniter yang melibatkan pihak-pihak yang berperang dan seringkali individu yang bertanggung jawab atas kekejaman dan kekejian tidak tersentuh oleh hukum. Untuk mengadili para pelaku kejahatan internasional harus diakui memang tidak mudah. Umumnya individu yang melakukan kejahatan berkelit pada legitimasi kedudukan resmi di negaranya. ${ }^{4}$ Sehingga

\footnotetext{
${ }^{1}$ E.Koeswara, Agresi manusia, Eresco, Bandung,1988, hlm. 151.

${ }^{2}$ Rogers A.P.V, Law On The Battlefield, Second Edition, Manchester University Press, United Kingdom, 200, hlm. 138.

${ }^{3}$ Quincy Wrigth, A Study of War, The University of Chicago Press, USA, 1965, hlm.1543.

${ }^{4}$ Ibid
} 
di perlukan suatu kekuatan dan kemauan yang lebih tinggi dari negara untuk mengadili pelaku-pelaku kejahatan tersebut.

Pasca perang dunia ke II dibentuklah Tokyo dan Nuremberg Tribunal sebagai upaya mengadili penjahat perang di Jepang dan Jerman pengadilan yang di tujukan untuk mengadili pelaku kejahatan Internasional yang digelar secara Adhoc, model pengadilan Adhoc menjadi pilihan di kemudian hari dalam upaya menyelesaikan beberapa konflik Hak asasi manusia sebagaimana International Criminal Tribunal For the Former Yugoslavia (ICTY) yang di gelar di Denhaag Belanda yang di bentuk sebagai pengadilan untuk mengadili pelaku- pelaku pelanggaran hukum humaniter dan kekerasan pada tahun 1991 pengadilan ini di gelar pada tahun 1993 dan berakhir pada tahun 2017 dan International Criminal Tribunal For Rwanda (ICTR) yang di bentuk mengadili orang yang bertanggung jawab atas terjadinya Genosida dan pelanggaran hukum internasional lain yang terjadi di Rwanda, pengadilan ini di gelar mulai 1 Januari hingga 31 Desember 1994di kota Arusha Tanzania. ${ }^{5}$

Hal inilah yang kemudian melatarbelakangi ide pembentukan pengadilan kriminal internasional dalam rangka memberikan kepastian dan keadilan hukum terhadap pelanggaran berat hak asasi manusia yang terjadi di berbagai kawasan dunia, kesepakatan secara internasional terhadap mekanisme, model penghukuman maupun lembaganya dianggap sebagai suatu bentuk keseriusan penanganan pelanggaran HAM Internasional. Hingga pada tanggal 17 Juli 1998 Statuta roma disahkan sebagai landasan hukum internasional mengatur tentang kejahatan terhadap kemanusiaan yang disahkan yang kemudian menjadi dasar pembentukan Mahkamah Pidana Internasional atau 1CC ( international Criminal Court), dimana salah satu yurisdiksinya adalah mengadili para pelaku kejahatan terhadap kemanusiaan, Statuta Roma juga memuat dasar-dasar suatu tindakan atau perbuatan yang dikualifikasikan ditetapkan sebagai kejahatan terhadap kemanusiaan dan yang dikutuk masyarakat internasional sebagai hostis humanis generis. ${ }^{6}$

Mahkamah pidana internasional sebagai suatau lembaga peradilan diharapkan mampu untuk meningkatkan kerjasama internasional dalam mengadili kejahatan-kejahatan paling serius yang merupakan keprihatinan internasional dan menjadi mekanisme penegakan keadilan supranasional yang mampu melindungi nilai-nilai dasar kemanusiaan dan memberikan peringatan bahwa dimasa yang akan datang tidak akan ada toleransi terhadap impunitas bagi setiap pelanggarannya. ${ }^{7}$

\footnotetext{
${ }^{5}$ Ibid

${ }^{6}$ Muladi, Hak Asasi Manusia, Hakekat, Konsep dan Implikasinya dalam Perspektif Hukum dan Masyrakat, Refika Aditama, Bandung,2007.hlm.128-130.

${ }^{7}$ Erikson Hasiloan Gultom (Prakata: Todung Mulya Lubis dan Albert Hasibuan), Kompetensi Mahkamah Pidana Internasional dan Peradilan Kejahatan Terhadap Kemanusiaan di Timor-timur, TataNusa, Jakarta,2006, hlm.225-256.
} 
Mahkamah Pidana International (ICC) secara resmi di buka di Den Haag tanggal 11 Maret 2003. ${ }^{8}$, dan hanya berlaku pada kejahatan setelah statuta Roma berlaku pada tahun 1998 sesuai dengan asas non retroaktif dari hukum bahwa hukum tidak dapat berlaku surut ${ }^{9}$. yang termuat dalam pasal 24 Statuta Roma dimana dalam pasal ini menyebutkan tentang Ratione Personae Non-retroaktif yang berarti :

1. Tidak seorang pun bertanggung jawab secara pidana berdasarkan Statuta ini atas perbuatan yang dilakukan sebelum diberlakukannya Statuta ini.

2. Dalam hal ada perubahan dalam hukum yang dapat diterapkan kepada suatu kasus tertentu sebelum keputusan akhir Mahkmah, maka berlaku hukum yang lebih menguntungkan bagi orang yang sedang diselidiki, dituntut atau dihukum. ${ }^{10}$

Mahkamah memiliki International legal Personality dan juga National legal Personality meskipun secara tersirat mahkamah memiliki kedudukan hukum baik sebagai subyek hukum Internsional maupun sebagai subyek hukum nasional dalam wilayah Negara pesertanya ataupun Negara bukan pesertanya yang didasarkan persetujuan tertentu sesuai dengan pasal 4 ayat 2 Statuta Roma, sebagai suatu lembaga Peradilan Pidana Internasional Mahkamah memiliki 4 yurisdiksi yakni yuridiksi personal, yuridiksi kriminal, yuridiksi teritorial dan yuridiksi temporal. ${ }^{11}$

Pemberlakuan Yuridiksi Mahkamah Internasional harus memenuhi prinsip Admissibility (penerimaan) yang memuat dua kriteria yaitu Ketidakinginan (unwillingness) secara sunguhsungguh untuk melaksanakan yuridiksi nasional dan ketidakmampuan (inability) untuk melaksanakan yuridiksi nasional secara benar. ${ }^{12}$ Prinsip ini menegaskan bahwa yurisdiksi Mahkamah hanya dapat menggantikan yuridiksi pengadilan nasional apabila pengadilan nasional telah menunjukkan ketidakmampuan atau kemauan untuk menuntut dan mengadili kejahatan serius yang terjadi dinegaranya. ${ }^{13}$ Kriteria untuk membuktikan adanya ketidakmampuan pengadilan Nasional tertuang dalam pasal 17 ( 3) bahwa, telah terjadi suatu keadaan kolaps atau kacau terhadap sarana dan prasarana pengadilan nasional sehingga pengadilan tidak mampu menghadirkan tertuduh atau mengajukan bukti-bukti cukup dan kesaksian atau tidak dapat melaksanakan tugas secara optimal dan yang menjadi criteria untuk

\footnotetext{
${ }^{8}$ Hans Peter Kaul, Development at The International Criminal Court:Contruction Site for More Justice: The ICC Afther Two Year, April 2005 , hlm 170

${ }^{9}$ R. Abdoel Djamali, Pengantar Hukum Indonesia,RajaGrafindo Persada, cet 10, Jakarta,2005, Hlm 179

${ }^{10}$ Mahkamah Pidana Internasional : Statuta Roma, Hukum Acara, dan Unsur -Unsur Kejahatan, Elsam, Jakarta, hlm 30

${ }^{11}$ Fadillah Agus,Pengantar Hukum Internasional dan Hukum Humaniter Internasional, Jakarta, Elsam, hlm 14

${ }^{12}$ Romli Atmasasmita, Hukum Pidana Internasional, Bag II, Jakarta, PT Hecca Mitra Utama, 2004,hlm 13

13 ibid
} 
membuktikan ketidakinginan yang sungguh-sungguh dari pengadilan nasional untuk mengadili dicantumkan dalam pasal 7 ( 2) yang menegaskan. ${ }^{14}$

1. Langkah-langkah hukum sudah atau sedang dilakukan atau keputusan nasional diambil untuk tujuan melindungi orang yang bersangkutan dari tanggung jawab pidana atas kejahatan yang berada di bawah jurisdiksi Mahkamah sebagaimana tercantum dalam pasal 5;

2. Ada suatu penangguhan yang tidak dapat dibenarkan dalam langkah-langkah hukum yang dalam keadaan itu tidak sesuai dengan maksud untuk membawa orang yang bersangkutan ke depan Mahkmah;

3. Langkah-langkah hukum dulu atau sekarang tidak dilakukan secara mandiri atau tidak memihak, dan langkah-langkah tersebut dilakukan dengan cara di mana, dalam hal itu, tidak sesuai dengan maksud untuk membawa orang yang bersangkutan ke depan Mahkamah.

Jurisdiksi Mahkamah terbatas pada kejahatan paling serius yang menyangkut masyarakat internasional secara keseluruhan. Dimana kejahatan tersebut harus memenuhi kualifikasi yang pertama harus terjadi konflik bersenjata baik Internal maupun Internasional pada saat kejahatan dituduhkan telah dilakukan dan yang kedua harus ada hubungan erat antara konflik bersenjata dengan kejahatan yang dituduhkan artinya bahwa tindakan pelaku harus terkait erat dengan peperangan ${ }^{15}$.

Mahkamah mempunyai jurisdiksi sesuai dengan Statuta berkenaan dengan kejahatankejahatan berikut ${ }^{16}$ :

1. Kejahatan genosida sebagai kejahatan pembasmian tertentu berdasarkan ras dan agama $^{17}$. Atau dalam ketentuan Pasal 6 Statuta Roma yang menyatakan bahwa Genosida berarti setiap perbuatan yang dilakukan dengan tujuan untuk menghancurkan, seluruhnya atau untuk sebagian, suatu kelompok nasional, etnis, ras atau keagamaan. Tindakan dari Genosida haruslah bersifat massif atau berskala besar untuk mengakibatkan kehancuran total atau sebagian dari kelompok nasional, etnis, ras atau keagamaan

Elemen Genosida dapat diilustrasikan sebagai berikut ${ }^{18}$ :

\footnotetext{
${ }^{14}$ Idem, hlm 17

${ }^{15}$ Human Right Watch, Genosida Kejahatan Perang dan Kejahatan Terhadap Kemanusiaan: Saripati Kasus Pelanggaran HAM berat dalam ICTY, Jilid II, Elsam, Jakarta,2007

${ }^{16}$ Statuta Roma

${ }^{17}$ Romli Atmasasmita, Pengantar Hukum Pidana Internasional, PT Refika Aditama, Jakarta, cet 3 2006,hlm 45

${ }^{18}$ Rhona K.M. Smith, Njal Hostmaelingen, ( et. Ol), Hukum HAk Asasi Manusia, PUSHAM UII, Yogyakarta, 2008, hlm 330
} 


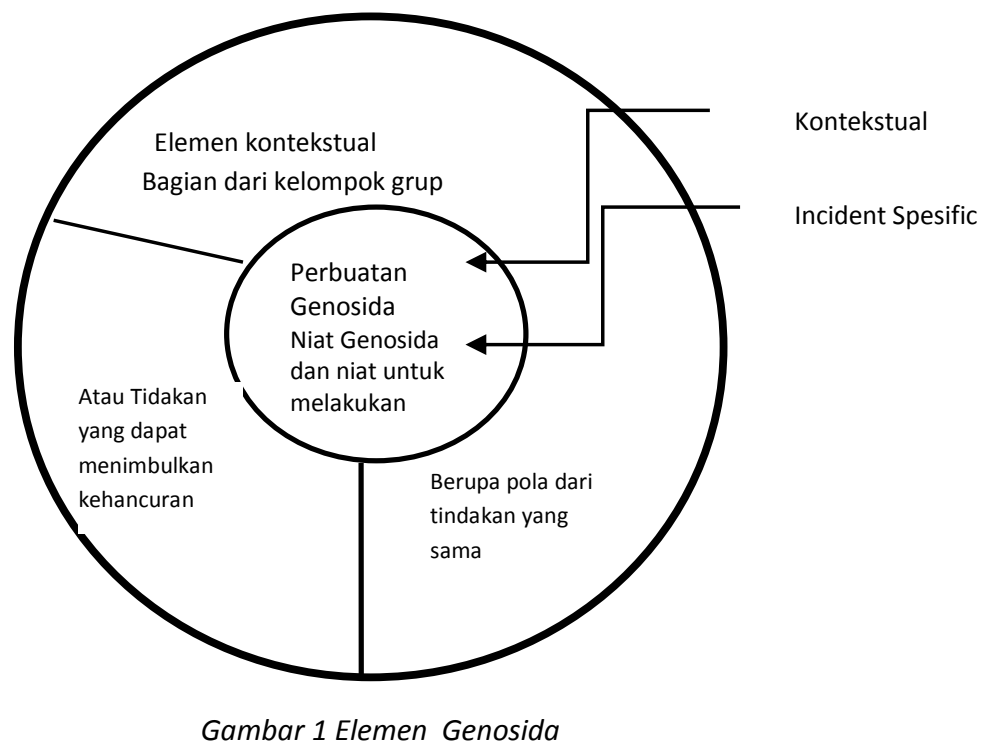

2. Kejahatan terhadap kemanusiaan; Pasal 7 Statuta Roma yang menyatakan bahwa kejahatan terhadap kemanusiaan" berarti salah satu dari perbuatan berikut ini apabila dilakukan sebagai bagian dari serangan meluas atau sistematik yang ditujukan kepada suatu kelompok penduduk sipil, dengan mengetahui adanya serangan itu: Pembunuhan; b) Pemusnahan; c) Perbudakan; d) Deportasi atau pemindahan paksa penduduk; e) Pemenjaraan atau perampasan berat atas kebebasan fisik dengan melanggar aturan-aturan dasar hukum internasional; f) Penyiksaan; g) Perkosaan, perbudakan seksual, pemaksaan prostitusi, penghamilan paksa, pemaksaan sterilisasi, atau suatu bentuk kekerasan seksual lain yang cukup berat; h) Penganiayaan terhadap suatu kelompok yang dapat diidentifikasi atau kolektivitas atas dasar politik, ras, nasional, etnis, budaya, agama, gender sebagai didefinisikan dalam ayat 3 , atau atas dasar lain yang secara universal diakui sebagai tidak diizinkan berdasarkan hukum internasional, yang berhubungan dengan setiap perbuatan yang dimaksud dalam ayat ini atau setiap kejahatan yang berada dalam jurisdiksi Mahkamah; i)

Penghilangan paksa; j) Kejahatan apartheid; k) Perbuatan tak manusiawi lain dengan sifat sama yang secara sengaja menyebabkan penderitaan berat, atau luka serius terhadap badan atau mental atau kesehatan fisik.

3. Kejahatan perang; kejahatan perang berarti Pelanggaran- pelanggaran terhadap hukum Humaniter International yang mengakibatkan tanggung jawab secara individu dari pelaku. ${ }^{19}$ dimana dalam hukum humaniter Internasional dianut beberapa asas yakni

\footnotetext{
${ }^{19}$ Ibid
} 
a. Asas kepentingan militer ( military necessity), artinya pihak bersengketa dibenarkan menggukhakan kekerasa ubtuk menundukkan lawan demi tercapainya tujuan keberhasilan perang

b. asas perikemanusiaan ( Humanity) artinya dilarang menggunakan kekerasan yang dapat menimbulkan luka yang berlebihan atau penderitaan yang tidak perlu

c. asas kesatriaan ( chivalry) artinya dalam perang kejujuran harus diutamakan, penggunaan alat-alat yang tidak terhormat berbagi macam tipu muslihat dan caracara yang bersifat khianat dilarang ${ }^{20}$

4. Pelanggaran berat terhadap Konvensi Jenewa tertanggal 12 Agustus 1949, yaitu masing-masing dari perbuatan berikut ini terhadap orang-orang atau hak-milik yang dilindungi berdasarkan ketentuan Konvensi Jenewa yang bersangkutan:

a. Pembunuhan yang dilakukan dengan sadar;

b. Penyiksaan atau perlakuan tidak manusiawi, termasuk percobaan biologis;

c. Secara sadar menyebabkan penderitaan berat, atau luka serius terhadap badan atau kesehatan;

d. Perusakan meluas dan perampasan hak-milik, yang tidak dibenarkan oleh kebutuhan militer dan dilakukan secara tidak sah dan tanpa alasan;

e. Memaksa seorang tawanan perang atau orang lain yang dilindungi untuk berdinas dalam pasukan dari suatu Angkatan Perang lawan;

f. Secara sadar merampas hak-hak seorang tawanan perang atau orang lain yang dilindungi atas pengadilan yang jujur dan adil;

g. Deportasi tidak sah atau pemindahan atau penahanan tidak sah;

h. Menahan sandera.

5. Kejahatan agresi. belum berlaku karena definisi berdasarkan undang -undang untuk pelanggaran ini masih dalam penundaan. ${ }^{21}$

Mahkamah adalah suatu lembaga hukum yang perspektif dalam arti bahwa ia tidak boleh melaksanakan yurisdiksinya atas kejahatan-kejahatan yang terjadi sebelum berlakunya statuta. ${ }^{22}$ Dari sinilah muncul persolan bagaimanakah penyelesaikan kasus pelanggaran HAM berat yang bertentangan dengan statuta ini yang terjadi sebelum tahun 1998 jika sebelum lahirnya ketentuan tentang Mahkamah Pidana Internasinal. Mahkamah Internasional dalam rangka menyelesaikan Kasus pelanggaran HAM berat menggunakan system Pengadilan Ad Hoc seperti pembentukan ICTY dan ICTR ${ }^{23}$.

\footnotetext{
${ }^{20}$ Arlina Permanasari, Pengantar Hukum Humaniter, ICRC, Jakarta, 1999, hlm 3

${ }^{21}$ Manfred Nowak, Pengantar pada Rezim HAM Internasional,Penerjemah Sri Sulastini,Martinus Nijhoff Publishers.2003, hlm 320

${ }^{22}$ Boer Mauna, Hukum Internasional edisi 2, Alumni,Bandung, 2005, hlm 299

${ }^{23}$ Ideh, hlm 286
} 
Kedua pengadilan Ad Hoc tersebut di bentuk sebelum lahirnya Mahkamah Pidana Internasional, karenanya diperlukan suatu formula hukum yang memberikan legitimasi pelaksanaan pengadilan terhadap Pelanggaran HAM yang terjadi sebelum pembentukan Mahkamah Pidana Internasional namun tidak bertentangan dengan Asas Non Retroaktif dari hukum Mahkamah Pidana Internasional yang telah di bentuk ternyata memeliki beberapa kendala terutama keterbatasan yurisdiksi waktu dan tempat dari ICC maka, dibentuklah model baru institusi pengadilan internasional dengan mengkombinasikan elemen-elemen nasional dan internasional yang dikenal dengan "Hybrid Court"

Berdasarkan uraian latar belakang tersebut, penulis merumuskan permasalahan yaitu; Bagaimana penerapan Hybird Court sebagai solusi alternatif dalam menyelesaikan kasus Kejahatan Hak Asasi Manusia yang terjadi di sebuah Negara.

\section{B. PEMBAHASAN}

\section{Peran dan fungsi Hybrid Court atau Mixed dalam kedudukannya sebagai pengadilan alternatif dalam penyelesaian sengketa Hak Asasi Manusia.}

\section{a. Hybrid Court atau Mixed Court}

Hybrid Court atau Mixed Court merupakan sebuah tribunal yang menggabungkan hukum internasional dengan nasional, termasuk aparatur pengadilannya. ${ }^{25}$ Dalam artian Hybrid Court dapat diartikan sebagai pengadilan nasional yang diinternasionalkan (internationalized of domestic tribunals). Pengadilan ini merupakan lembaga independen dan dibentuk atas dasar perjanjian antara PBB dan negara Mixed Tribunal atau yang dikenal dengan sebutan Hybrid Court sebuah tribunal yang menggabungkan hukum internasional dengan nasional, termasuk aparatur pengadilannya ${ }^{26}$.

Hybrid Court merupakan suatu bentuk Pengadilan khusus ini dibentuk untuk mengadili orang-orang yang bertanggungjawab terhadap, crimes against humanity, violations of Article 3 common to the Geneva Conventions and of Additional Protocol II, Other serious violations of international humanitarian Law', s. Pengadilan khusus ini mempunyai primacy terhadap pengadilan nasional, dan berlaku Asas ne bis in idem terhadap perkara yang telah disidangkan terlebih dahulu kecuali terbukti bahwa pengadilan terdahulu tidak menerapkan asas fairness dalam artian pengadilan terdahulu tidak menjamin sifat tidak memihak atau independensi, untuk melindungi tersangka atau penuntutan tidak dilakukan secara sungguh-sungguh.

\footnotetext{
${ }^{24}$ Shaw N.Malcolm , International Law, Seconnd Edition, Cambridge: Grotius Publication Limited, New York, 2008,hlm.417

${ }^{25}$ Papang Hidayat, Komisi Kebenaran dan Rekonsiliasi; Alternatif Penyelesaian Kejahatan HAM Masa Lalu?, www.kontras.org. 31 Desember 2011

${ }^{26}$ Ibid.
} 
Hybrid Court sebagai suatu model peradilan dikenal sebagi Hybrid model merupakan kombinasi peradilan yang berisis komposisi hakim pada 'Trial Chamber' yang berjumlah 3 orang, satu orang ditunjuk oleh pemerintah Nasional dan dua orang hakim ditunjuk oleh Sekretaris Jenderal PBB. Selanjutnya 5 hakim pada 'Appeal Chamber', dua ditunjuk oleh Pemeritahan Nasional dan 3 hakim ditunjuk oleh Sekretaris Jenderal PBB. Sementara Jaksa (Prosecutor) ditunjuk oleh Sekretaris Jenderal PBB selama 3 tahun dan dapat dipilih kembali, dibantu oleh Deputy Prosecutor yang berasal dari Pemerintahan Nasional serta staf internasional demi effisiensi dan Efektivitas, Mengingat banyak kasus yang berkaitan dengan perkosaan, serangan seksual, dan kejahatan seksual lain yang menyangkut wanita dan anak-anak serta penculikan dan perbudakan, maka staf jaksa dan penyilidik banyak yang mempunyai pengalaman, 'gender-related crimes and juvenile justice'. Panitera juga ditunjuk oleh Sekretaris Jenderal PBB setelah konsultasi dengan Ketua Pengadilan Khusus dan berasal dari anggota staf PBB untuk jangka waktu 3 tahun dan bisa diperpanjang. Bahasa yang digunakan adalah bahasa Inggris. Ketua Pengadilan harus mengirimkan laporan tahunan kepada Sekretaris JenderaI PBB dan Pemerintah Nasional. $^{27}$

Hybrid Court bertujuan untuk menghindari masalah-masalah proses peradilan secara nasional secara penuh dan proses peradilan secara internasional, seperti International Criminal Tribunals for the former Yugoslavia (ICTY), Rwanda (ICTR) dan International Criminal Court (ICC). Model Hybrid Court ini berusaha untuk mengkombinasikan kekuatan pengadilan ad hoc dengan keuntungan penuntutan secara nasional, jadi dapat dikatakan bahwa model hybrid ini menggabungkan pengadilan nasional dan penuntutan internasional dalam kejahatan internasional.

Menurut Dickinson, salah satu hal yang menarik dalam Hybrid Court ini adalah dalam area legitimasi, kapasitas dan norma, sementara dalam pengadilan nasional kadangkala masih terdapat kurangnya legitimasi karena suatu institusi pengadilan yang seharusnya tidak memihak dan independen tidak melakukan hal-hal tersebut. Pengadilan yang dilakukan secara internasional seperti International Criminal Tribunal for Former Yugoslavia ICTY), International Criminal Tribunal for Rwanda (ICTR) dan juga International Criminal Court (ICC) dianggap kurang dalam hal legitimasi karena bagi mereka yang telah menjadi korban yang secara nyata "memiliki" pengadilan ini tidak dapat menghadirinya dikarenakan pengadilan tersebut diadakan di tempat yang cukup jauh, dan para pembela tidak cukup mengenal konflik yang terjadi. ${ }^{28}$

\footnotetext{
${ }^{27}$ Muladi. Peradilan hak asasi manusia dalam konteks Nasional dan internasional, www.Ifip.org

${ }^{28}$ Ibid
} 
Menegakan supremasi hukum dan kebebasannya dari pertimbanganpertimbangan politik akan memiliki peran yang sangat penting dalam pemberian kontribusi tersebut, untuk alasan tersebut pada dasarnya Hybrid Court akan memberikan aspirasi terhadap standar-standar yang tinggi akan kemandirian (independence), ketidakberpihakan (impartiality), dan aplikasi-aplikasi dari norma-norma akan suatu proses peradilan yang jujur serta penegakan hak asasi manusia internasional. Pengalaman membutikan bahwa ada bentuk pengaruh secara tidak langsung yang belum secara mendalam dianalisa, tetapi ada beberapa area dimana pengaruh-pengaruh tersebut, yaitu: ${ }^{29}$

1) Standar-standar proses peradilan (fair trial standards). Pendekatan terhadap isu-isu proses peradilan yang jujur dan prinsip kesamaan berpotensi menuntun terhadap pengakuan terhadap pentingnya aturan-aturan dari pembelaan

2) ( prosecutorial standars). Standar-standar penuntutan dalam hubungannya dengan proses peradilan yang jujur adalah dalam adanya pengadaan bukti-bukti. Tidak menuntut kasus dengan bukti-bukti yang tidak cukup, membuat korban-korban untuk mengetahui hak-haknya, dan bertindak tidak memihak.

3) Tranparasi terhadap institusi-institusi publik dan tingkat profesionalisme (tranperancy of public institutions and levels of professionalism). Institusi-institusi hybrid yang dibentuk harus mudah diakses dan transparan dalam hal informasi agar dapat berjalan dengan baik. Informasi-informasi yang jelas akan memberikan dampak yang positif terhadap bagaimana Hybrid Court tersebut berjalan mengenai Hybrid Court tersebut harus dapat diakses oleh para pegawai

4) Hal-hal yang berhubungan dengan finansial atau keuangan. Hal ini juga merupakan merupakan pertimbangan-pertimbangan yang sangat penting

5) Standar-standar etika dan aturan mengenai tingkah laku (code of conduct).

6) Standar-standar mengenai penahanan dan pemenjaraan. (standards for detention and imprisionment). Keberadaan Hybrid Court dapat memberikan kesempatan untuk menampilkan standar-standar internasional penahanan dan pemenjaraan.

7) Isu -isu mengenai gender. Kebijakan-kebijakan yang kuat baik mengenai penuntutan kejahatan -kejahatan gender dan kesetaraan gender dapat merubah tatanan sosial dimana wanita mendapat status yang lebih rendah di masyarakat.

Pengaruh yang begitu besar yang mampu di isi oleh Hybrid Court menjadi salah satu alasan mengapa Hybrid Court dianggap sebagai solusi dari kevakuman dan kebuntuan penanganan kasus sengketa pelanggaran HAM berat yang terjadi diberbagai

${ }^{29}$ Rule -of Law Tool For Post Conflict States, Maximizing the Legacy of Hybrid Court, dalam www.ohrc.com, diakses pada tanggal 4 April 2011 
negara. Selain daripada itu Pengadilan campuran atau Hybrid Court menjadi pilihan model pengadilan Internasional dibandingkan model Internasional dikarenakan beberapa alasan berikut ini: ${ }^{30}$

1) Pembentukan tribunal internasional perlu mendapat persetujuan dari semua anggota tetap dewan keamanan PBB. Pada kenyataannya Rusia, China dan Amerika Serikat terus menerus menentang pembentukan tribunal baru dengan alasan-alasannya antara lain adalah bahwa di kemudian hari akan ada kemungkinan di mana situasi hak asasi dalam negeri mereka sendiri menjadi obyek dari tribunal kejahatan internasional yang akan dibentuk.

2) Sampai tahun 2002, biaya operasional dua tribunal kejahatan PBB telah mencapai USD 250 juta per tahun, sekitar 15\% dari keseluruhan biaya operasional PBB, dengan jumlah pegawai 2000 orang. Fakta bahwa tribunal-tribunal tersebut bertempat di luar negara-negara di mana pelangggaran-pelanggaran terjadi telah menimbulkan biaya-biaya yang sangat tinggi untuk perjalanan, akomodasi dan biaya-biaya terkait untuk para staff, saksi, penuntut, pembela dan hakim and ahli internasional lainnya.

3) Tribunal Internasional patut dipertanyakan. Tribunal-tribunal tersebut berlokasi di tempat yang jauh sekali, penduduk lokal tidak bisa datang ke persidangan, persidangan dilaksanakan oleh orang asing menggunakan bahasa asing, para korban mendapatkan sedikit akses untuk informasi sehubungan dengan persidangan. Masalah ini disebut sebagai fenomena 'spaceship' (pesawat ruang angkasa) - di mana orang lokal merasa tribunal merupakan hal yang asing, jauh di luar pemahaman mereka, dan berlokasi di tempat yang jauh sekali.

4) Walaupun dua tribunal internasional sebelumnya (ICTR dan ICTR) telah memakan biaya yang luar biasa besar, hanya sedikit pelaku yang diadili. Membentuk sebuah pengadilan yang benar-benar baru dan jauh dari konteks kejahatan memerlukan sejumlah besar 'pekerjaan awal' dan biaya, yang berarti bahwa pada tahun-tahun pertama kegiatan operasional tribunal hanya sedikit hasil yang terlihat.

5) Meskipun banyak halangan dalam pembentukan tribunal internasional, negaranegara yang timbul dari pelanggaran massa, seperti Kosovo, Timor Timur dan Kamboja merasa perlu adanya satu bentuk pertanggungjawaban atas apa yang telah terjadi. Hal ini penting untuk memenuhi hak para korban untuk mendapatkan tanggapan yang memfasilitasi penyembuhan nasional, yang menyediakan forum publik yang mana bukti sehubungan dengan kejahatan masa lalu dapat ditayangkan/disiarkan, membawa pesan yang jelas bahwa tidak akan ada

\footnotetext{
${ }^{30}$ Kursus HAM untuk Advokat, dalam Website www.elsam.org , diakses pada November 2011 Pukul 15.00
} 
pengampunan atas bentuk kejahatan serupa yang dilakukan di masa yang akan datang, dan membangun kredibilitas dan dukungan atas hukum di bawah rezim baru.

6) Sistem pengadilan, penuntutan dan polisi dalam situasi pasca konflik ini menempati posisi yang sangat lemah. Agar dapat menangani kejahatan internasional yang kompleks struktur lokal memerlukan bantuan internasional yang signifikan. Hal ini juga menyediakan peluang untuk perkembangan kapasitas.

7) Situasi politik dalam negeri menciptakan tantangan untuk mencapai kemerdekaan, pengadilan imparsial. Hal ini dibantu oleh partisipasi hakim-hakim internasional dan para ahli lainnya, dan oleh keterlibatan PBB.

8) Dengan keikutsertaan hakim-hakim lokal dan pejabat lainnya dalam prosesnya menciptakan semangat bahwa hal ini adalah merupakan mekanisme nasional, bukan sesuatu yang dibentuk oleh dan bagi pihak asing

9) Memajukan dialog mengenai hak asasi manusia. Sumbangan-sumbangan secara kritis bisa diberikan terhadap suatu budaya. Tribunal-tribunal yang dibentuk oleh PBB pada satu sisi terlihat seperti adanya ambiguitas, tribunal-tribunal yang tersebut terlihat seperti mengacu kepada aspek nasional dan internasional. dengan pengadilan domestik terlihat seperti tribunal-tribunal tersebut menggantikan pengadilan domestik suatu negara.

\section{b. Special Court for Sierra Leone dan Extra Chamber Court of Cambodian (ECCC)}

Model pengadilan hybrid dikelompokan dari beberapa campuran negara-negara dan komponen internasional yang menawarkan pendekatan yang tertuju pada keadilan internasional secara keseluruhan pada satu sisi dan keadilan dalam negeri di sisi lain ${ }^{31}$

Hybrid Court atau pengadilan campuran didefinisikan sebagai pengadilan campuran dari komposisi dan yurisdiksi, baik dari aspek nasional dan internasional, biasanya di terapkan di dalam wilayah dimana kejahatan itu terjadi. ${ }^{32}$ Model pengadilan ini merupakan pengadilan campuran dari aspek internasional dan nasional, merupakan suatu produk hukum yang buat oleh suatu negara dan entitas internasional yang secara khusus adalah PBB.

\footnotetext{
${ }^{31}$ Sarah M.H Nouven,' Hybrid Court' The Category of a New Type of International Criminal Court, Utrech Law Review, Igitur, 2006, hIm 190-200

${ }^{32}$ Rule -of Law Tool For Post Conflict States, Maximizing the Legacy of Hybrid Court, dalam www.ohrc.com, diakses pada tanggal 4 April 2011
} 
Jenis pengadilan ini sering kali didirikan dalam hal tersangka atau terdakwa dalam beberapa kasus yang serius (serious crimes) seperti kejahatan perang, kejahatan terhadap kemanusiaan yang dituduhkan kepada mereka. Sebagian besar tersangka atau terdakwa menghadapi sistem hukum yang belum siap untuk menyelesaikan kasus-kasus tersebut. Pada situasi-situasi setelah konflik, pengadilan domestik akan menghadapi masalah-masalah sistemik termasuk hukum yang tidak memadai, kesewenag-wenangan, inkompentensi, kondisi yang memprihatinkan, kurangnya akses terhadap keadilan termasuk tidak memadainya perwakilan ahli hukum. ${ }^{33}$

Pengadilan ini sering disebut "pengadilan campuran" adalah pengadilan yang melibatkan majelis hakim yang terdiri dari hakim nasional dan hakim internasional. Di Kosovo, Timor-Leste dan Kamboja, pengadilan ini didirikan sebagai bagian dari pengadilan domestik, melalui undang-undang nasional. Sedangkan di Sierra Leone, negara tersebut membuat perjanjian dengan PBB yang kemudian menjadi landasan hukum untuk pengadilan tersebut. ${ }^{34}$ tribunals, atau mixed international/ national institutions ${ }^{35}$ Sampai saat ini tercatat ada 3 buah peradilan semacam ini yakni Sierra leone. Kosovo dan kamboja

\section{c. Special Court for Sierra Leone (Mahkamah khusus untuk Sierra Leone)}

Mahkamah ini di bentuk pada bulan januari 2002 atas dasar persetujuan antara pemerintan Sierra leone dan PBB yang merupakan Mixed Tribunal yaitu mahkamah yang bertugas untuk menuntut dan mengadili orang-orang yang bertanggung jawab atas kejahatan terhadap kemanusiaan Kejahatan Perang pelanggaran berat lainnya terhadap hukum humaniter Internasional yang terjadi di Sierra Leone semenjak tanggal 30 November 1996. Awal mula peperangan terjadi pada 23 Maret 1991, negara di Afrika Barat yaitu di Sierra Leone telah terjadi pertikaian dan kekerasan antara Revolutionary United Front (RUF) yang dipimpin oleh Foday Sankoh dan pihak rezim dari All People's Congress (APC). ${ }^{36}$ Akibat konflik tersebut tercatat 2 juta Orang mengungsi dan 100.000 orang dibunuh, serta ribuan perempuan menjadi korban kekerasan seksual. Konflik di Sierra Leone juga terkenal dengan praktek amputasi tangan dan kaki, serta rekrutmen paksa anak-anak paksa anak-anak oleh pihak-pihak yang berkonflik.

Pada tahun 1999, pemerintah Sierra Leone dan RUF (tentara pemberontak) menanda tangani sebuah kesepakatan perdamaian yang juga memberi amnesti untuk semua pihak. Tetapi perang pecah kembali, dan amnesti di batalkan. Sebuah perjanjian

\footnotetext{
${ }^{33}$ Ibid

${ }^{34}$ Sebuah Buku Acuan Untuk Praktisi, Hukum Pidana Internasional dan Perempuan, Publikasi KOMNAS HAM

35 Rule -of Law Tool For Post Conflict States, Maximizing the Legacy of Hybrid Court, dalam www.ohrc.com, diakses pada tanggal 4 April 2011 pukul 14.00 WIB

${ }^{36}$ Ilas Bantekas \& Susan Nash, International Criminal Law, Op.,Cit.,hlm.397
} 
internasional antara pemerintah Sierra Leone dan PBB di tandatangani untuk mendirikan pengadilan khusus yang akan berjalan selama 3 tahun untuk mengadili "mereka yang paling bertanggung jawab atas kejahatan yang paling berat".

Pengadilan Khusus ini menggunakan standar hukum internasional yang dikembangkan di ICTY dan ICTR. Sebuah unit khusus untuk penyidikan kejahatan seksual di bentuk oleh tim jaksa penuntut yang pada saat ini menyiapkan dakwaan termasuk untuk kasus -kasus" perkawinan paksa Pemerintah Sierra Leone meminta kepada PBB untuk mendirikan tribunal pengadilan internasional untuk menuntut siapa saja yang bertanggung jawab terhadap hukum humaniter internasional selama perang sipil. The Special Court for Sierra Leone didirikan oleh perjanjian antara pemerintah Sierra Lieone dengan PBB berdasarkan permintaan Presiden Sierra Leone kepada Dewan Keamanan PBB. Special Court ini di bentuk untuk mengadili para pelaku kejahatan perang. ${ }^{37}$

Pada tanggal 14 Agustus 2000 The special Court for Sierra Leone terbentuk dan memiliki yurisdiksi pengadilan untuk mengadili kejahatan-kejahatan di bawah hukum humaniter internasional dan hukum nasional Sierra Leone meliputi: ${ }^{38}$

1) Kejahatan terhadap kemanusiaan

2) Pelanggaran terhadap pasal Konvensi Jenewa 1949 beserta Protokol Tambahan II

3) Pelanggaran terhadap pasal 4 Konvensi Jenewa, termasuk dengan sengaja menjadikan penduduk sipil sebagai sasaran, horse de combat, penculikan dan pembunuhan terhadap personil yang membawa misi perdamaian, dan memaksakan anak-anak dibawah umur 15 tahun untuk ikut berparisipasi secara aktif dalam perang.

\section{d. Extra Chamber Court for Cambodia/ECCC}

Majelis ini (Extra Chamber Court for Cambodia/ECCC) dibentuk atas dasar perjanjian antara pemerintah kamboja dan PBB pada tahun 1997 dalam rangka mandat mengadili pemimpin Khmer Merah yang masih hidup atas dakwaan kejahatan terhadap kemanusiaan. Mereka antara lain mantan Panglima Tentara Khmer Merah Ta Mok, kepala interogator Kaing Khek Iev, presiden Khieu Samphan, menteri luar negeri Ieng Sary, dan Nuon Chea yang dikenal sebagai "Kamrad Nomor Dua".

Setelah melalui bebagai hambatan politik pada akhirnya Oktober 2004 DPR dan Senat Kamboja menyetujui dan meratifikasi "Kesepakatan antara PBB dan Pemerintah Kerajaan Kamboja“. Isi kesepakatan sekaligus mengamandemen undang-

${ }^{37}$ Cyrer Robert,Friman Hakan, An Introducrion to International Criminal Law and Procedure, Op., Cit, hlm.151

${ }^{38}$ Idem hlm.399 
undang Kamboja dengan memasukkan peraturan pembentukan pengadilan khusus di dalam pengadilan Kamboja terhadap kejahatan selama periode rezim Khmer Merah. Kesepakatan baru tersebut membuka jalan bagi terbentuknya Majelis Pengadilan Khusus Kamboja pada 2004. Pengadilan yang dipimpin 17 orang hakim Kamboja dan 12 hakim internasional itu diumumkan tahun 2006.

Berdasarkan pasal 2 Perjanjian tersebut menyebutkan bahwa Extraordinary Chamber tersebut memiliki jurisdiksi yang terdapat undang-undang dalam hukum nasional Kamboja dan perjanjian tersebut diimplementasikan melalui perangkat undangundang tersebut. Terdapat juga Konvensi Wina 1969 tentang Perjanjian Internasional untuk mengimplementasikan perjanjian tersebut.Perjanjian tersebut harus dilihat sebagai perjanjian internasional, walaupun terdapat hubungannya dengan dengan hukum nasional. ${ }^{39}$

Keputusan yang dihasilkan didasarkan kepada kesepakatan, kemudian apabila kesepakatan tersebut tidak bisa dicapai maka pemungutan suara dimungkinkan untuk diterapkan dipengadilan tersebut. ${ }^{40}$

Jurisdiksi dari extraordinary chambers ini menyangkut berbagai pembunuhan, kekejaman dan kejahatan internasional seperti genosida, kejahatan terhadap kemanusiaan, pelanggaran berat terhadap Konvensi Jenewa dan kejahatan terhadap

${ }^{39}$ Pasal 2 Agreement Between the United Nations and the Royal Government of Cambodia Concerning the Prosecution Under Cambodian Law of Crimes Commited During the Periode of Democratic Kampuchea menyebutkan bahwa

1. The present Agreement recognizes that the Extraordinary Chambers have subject matter jurisdiction consistent with that set forth in "the Law on the Establishment of theExtraordinary Chambers in the Courts of Cambodia for the Prosecution of Crimes Committed During the Period of Democratic Kampuchea" (hereinafter: "the Law on the Establishment of the Extraordinary Chambers"), as adopted and amended by the Cambodian Legislature under the Constitution of Cambodia. The present Agreement further recognizes that the Extraordinary Chambers have personal jurisdiction over senior leaders of Democratic Kampuchea and those who were most responsible for the crimes referred to in

Article 1 of the Agreement.

2. The present Agreement shall be implemented in Cambodia through the Law on the Establishment of the Extraordinary Chambers as adopted and amended. The Vienna Convention on the Law of Treaties, and in particular its Articles 26 and 27, applies to the

Agreement.

3. In case amendments to the Law on the Establishment of the Extraordinary Chambers are deemed necessary, such amendments shall always be preceded by consultations betweenthe parties.

${ }^{40}$ Pasal 4 Agreement Between the United Nations and the Royal Government of Cambodia Concerning the Prosecution Under Cambodian Law of Crimes Commited During the Periode of Democratic Kampuchea

1. The judges shall attempt to achieve unanimity in their decisions. If this is not possible, the following shall apply:

a.decision by the Trial Chamber shall require the affirmative vote of at least four judges;

$b$. decision by the Supreme Court Chamber shall require the affirmative vote of at least five judges.

2. When there is no unanimity, the decision of the Chamber shall contain the views of the majority and the minority. 
orang-orang yang dilindungi menurut hukum internasional. Pada tangal 21 Januari 2001, Majelis Nasional Kamboja menyetujui pembentukan Extraordinary Chamber in the Court of Cambodia for the Prosecution of Crimes Commited During the Period of Democratic Cambodia. Adapun kejahatan yang dapat dituntut menurut law on Extraordinary Chamber adalah: ${ }^{41}$

1) Pasal 3 law on Extraordinary Chamber mengenai pembunuhan, penyiksaan dan penganiayaan religius diambil dari pasal 209, pasal 210, pasal 500, pasal 501, pasal 503, pasal 504, pasal 505, pasal 506, pasal 507, pasal 508 Kitab Undang-Undang Hukum Pidana (KUHAP) kamboja 1956

2) Pasal 4 Law on Extraordinary Chamber adalah mengenai genesida sesuai dengan Konvensi Genosida tahun 1948

3) Pasal 5 Law on Extraordinary Chamber terkait kejahatn terhadap kemanusiaan yang diambil dari Statue of the International Criminal Tribunal for Rwanda (ICTR)

4) Pasal 6 Law on Extraordinary Chambers menyangkut kejahatan perang yang secara terbatas meliputi pelanggaran berat terhadap Konvensi Jenewa 1949

5) Pasal 7 Law on Extraordinary Chamber adalah penegakan Konvensi Den Haag 154 tentang perlindungan Benda-Benda Budaya selama Konflik bersenjata

6) Pasal 8 Law on Extraordinary Chamber berkaitan dengan Konvensi Wina 1961 Mengenai Hubungan Diplomatik. Dalam hal ini dibahas kejahatan terhadap orangorang yang dilindungi menurut hukum internasional.

Komposisi dari Extraordinary Chamber in the Court of Cambodia terdiri dari, chambers and judicial office (mahkamah dan kantor peradilan) dan office of administration (kantor administrasi). Chamber and judiciary office beranggotakan para hakim yang berasal dari Kamboja dan PBB. Pada tingkat pertama (trial chambers), jumlah hakimnya terdiri dari 5 orang dengan komposisi 3 hakim Kamboja dan 2 hakim PBB. Sementara pengadilan banding melibatkan 7 hakim dengan komposisi 4 hakim Kamboja dan 3 hakim PBB. Sedangkan Majelis hakim pada Mahkamah Agung (supreme Court chamber) beranggotakan 7 hakim ( termasuk hakim banding dan hakim pada tingkat akhir) dengan ketentuan 4 hakim Kamboja dan 3 hakim PBB yang dipilih oleh Mahkamah Agung berdasarkan rekomendasi dari Sekjen PBB , Hakim-hakim tersebut harus mempunyai kompetensi dan pengalaman dalam hukum pidana, hukum internasional termasuk hukum humaniter internasional dan hukum hak asasi manusia .

Dalam perjanjian antara pemerintah Kamboja dan PBB juga terdapat dalam struktur ECCC independent co-investigation judges atau hakim-hakim independen yang

${ }^{41}$ Eddy.S.Hariej,Pengantar Hukum Pidana Internasional, Op.,Cit.,hlm.65. 
memeriksa hasil investigasi ( satu hakim kamboja dan satu hakim internasional) yang bertanggung jawab dalam hal penyelidikan, dan juga ada dua orang co prosecutor atau Penuntut Umun yang bertanggung jawab dalam hal penuntutan-penuntutan, penuntut umum dalam ECCC terdiri dari satu orang penuntut umum dari Kamboja dan satu orang penuntut umum internasional

Office of Administration adalah salah satu bagian dari struktur ECCC yang mengurusi masalah-masalah yang berkaitan dengan administrasi (court management) seperti hal-hal yang berhubungan dengan staff-staff atau personil pengadilan, keuangan, dan mengurusi urusan hubungan dengan masyarakat seperti keamanan dan keselamatan. ${ }^{42}$ Office of Administration dibantu oleh Deffence Support Section dan Victim Unit untuk menjalankan fungsinya dalam hal administrasi pengadilan.

Deputy Director yang ditunjuk oleh Sekjen PBB mempunyai tanggung jawab dalam penempatan semua staff-staff internasional dan semua masalah administrasi dari komponen internasional dari Extraordinary Chamber ini seperti: the Pre-TrialChamber, the co-investigating judges, the Prosecutors' office dan the office of administrasi) ${ }^{43}$

Pada pengadilan genosida di Kamboja tidak semua anggota Khemer Merah akan diadili. Hanya pejabat-pejabat senior Khemer Merah yang merencanakan dan memberikan perintah yang akan diadili, begitu juga dengan pihak-pihak yang paling bertanggung jawab dalam kejahatan genosida. Pejabat Khmer Merah yang tergolong dalam tingkat menengah dan bawah yang bukan merupakan pihak yang paling bertanggung jawab tidak akan diadili. ${ }^{44}$

\footnotetext{
${ }^{42}$ Pasal 8 Agreement Between the United Nations and the Royal Government of Cambodia Concerning the Prosecution Under Cambodian Law of Crimes Commited During the Periode of Democratic Kampuchea

1. There shall be an Office of Administration to service the Extraordinary Chamber, the Pre-Trial Chambers, the co-Investigating judge and Prosecutors' office.

2. There shall be a Cambodian Director of this office, who shall appointed by the Royal Government of Cambodia. The Director shall be responsible for the over management of Office of Administration, except in matters that are subject to United Nations rules and procedures.

3. There shall be an international Deputy Directore of the Office Administration, who shall be appointed by the Secretary-General. The Deputy Director shall be responsible for the requitment of all international staff and all administration of the international component of the Extraordinary Chambers, the pre-trial chamber, the co-investigating judges, the presecutors'Office and the Office of Administration. The United Nation and the Royal Government of Cambodia agree that, when an international Deputy Director has been appointed by the Secretary-General, the assignment of that person to that position by the Royal Government of Cambodia shall take place forthwith.

4. The Director and the Deputy Director shall cooperate in other to ensure an effective and efficient ${ }^{43} \mathrm{Ibid}$ functioning of the Administration.

${ }^{44}$ Usul sejarah (Khmer Merah Sejarah Kelam Kamboja) dalam website www.killingfieledsmuseum.com .diakses pada mei 2011 Pukul 14.00
} 
Pada pangadilan ini juga tidak berlaku posthumous trials sehingga hanya orangorang yang masih hidup yang akan diadili. Bagi para terdakwa pelaku genosida maka mereka akan diadili dengan tuntutan hukum maksimal seumur hidup dan minimal selama lima tahun penjara. Tidak akan ada tuntutan hukuman mati karena tuntutan tersebut tidak terkonstitusi di Kamboja. Sebagai tambahan, negara akan menarik kembali harta dan uang dari para terdakwa yang didapatkan dengan cara melanggar hukum dan melalui tindakan kriminal yang nantinya akan menjadi hak milik negara. ${ }^{45}$

Amnesti atau pengampunan bagi pihak-pihak yang diinvestigasi tidak di kenal dalam ECCC semua pihak yang terlibat akan didakwa dalam pengadilan. Beberapa hal juga yang menjadi penekanan dalam pengadilan genosida di Kamboja adalah bahwa pengadilan memiliki kekuasaan terbatas yang hanya dapat mengadili pejabat Khmer Merah dari periode 17 April 1975 sampai 6 Januari 1979 yang merupakan periode rezim Khmer Merah berkuasa. Selain itu, pengadilan ini hanya akan mengadili pihak-pihak individu sebagai terdakwa, sehingga tidak akan membawa institusi seperti negara ataupun organisasi sebagai terdakwa. ${ }^{46}$

\section{PENUTUP}

\section{Kesimpulan}

Hybrid Court atau Mixed Court sebagai bagian dari International Criminal Court ( ICC) / Mahkamah Pidana Internasional memberikan harapan baru penuntasam masalah penegakan Pelanggaran HAM yang terjadi sebelum adanya statute Roma 1998 yang menjadi landasan pembentukan Mahlamah Pidana Internasioanal,Peradilan dengan cara Hybrid Court atau mixed court yang dilaksanakan di Negara tempat terjadinya konflik tersebut membuktikan bahwa Mahkamah Pidana Internasioanl memang dibentuk dalam rangka melengkapi peradilan nasional disamping itu model Peradilan Hybrid Court pada prinsipnya dapat memengkas biaya berperkara dibandingkan apabila proses penyelesaian sengketa dengan pengadilan Ad Hoc yang telah dilaksanakan untuk menyelesaikan sengketa di Yugoslavia dengan pembentukan ICTY ( The International Tribunal for The Former Yugoslavia ) yang bermarkas di Den Haag demikian pula dengan pembentukan ICTR ( The International Crimnal Tribunal For Rwanda) yang bermarkas di Arusha Tanzania dalam rangka penyelesaian pelanggaran HAM berat Genosida di Rwanda.

\section{Saran}

\footnotetext{
${ }^{45}$ Asal-Usul sejarah (Khmer Merah Sejarah Kelam Kamboja) dalam website www.killingfieledsmuseum.com .diakses pada mei 2011 Pukul 13.00

${ }^{46}$ http:// www.vhrmedia.net/home/index. php.?id =view\&ad=4021\&lang Pukul 13.00
} 
Adapun saran-saran terhadap kesimpulan diatas adalah : Para negara-negara yang mempunyai mempunyai catatan sejarah kejahatan internasional di negaranya hendaknya menunjukan itikadnya yaitu keinginan dan kemampuannya untuk mengadili kejahatan tersebut apabila tidak menginginkan adanya intervensi dari negara-negara lainnya, yaitu dengan membentuk suatu sistem peradilan, aparat penegak hukum beserta peraturan perundang-undangan yang memenuhi standar untuk dapat menyelesaikan kasus-kasus kejahatan internasional yang telah terjadi, Bagi negara-negara yang tidak atau belum siap menjadi pihak dalam Statuta Roma apabila ingin menjadi negara peserta pada Statuta Roma tersebut maka negara-negara tersebut harus menyesuaikan standar-standar hukum pidana dengan standar internasional (standar ICC) serta harus siap bekerja sama dengan Jaksa ICC dalam hal proses investigasi dan penuntutan, dan apabila negara-negara tersebut belum ingin menyatakan terikat dengan ketentuan ICC karena berbagai pertimbangan (seperti Indonesia) maka hendaknya mengantisipasi dengan ketentuan hukum nasionalnya untuk memahami seluruh ketentuan startegis di dalamnya sebagai langkah persiapan ratifikasi.

\section{DAFTAR PUSTAKA}

Buku :

Agung Yudhawiranata, Indonesia dan Kebutuhan Meratifikasi Statuta Roma: Mahkamah Pidana Internasional : Statuta Roma, Hukum Acara, dan Unsur-Unsur Kejahatan, Jakarta, Elsam,2007

Amirudin \& Zainal Asikin, Pengantar Metode Penelitian Hukum.Rajawali Press, Jakarta,2004,h.115

Anom Suryo Putra, Teori hukum kritis, , Bandung, Citra Aditya Bakti2003.

Arlina Permanasari, Pengantar Hukum Humaniter, Jakarta, ICRC, 1999.

Boer Mauna, Hukum Internasional edisi 2, Bandung,Alumni, 2005.

Fadillah Agus,Pengantar Hukum Internasional dan Hukum Humaniter Internasional, Jakarta, Elsam, 2008

Gusrini Tambuna, ( Eds.), Suatu Manual: Prinsip - Prinsip Panduan bagi Internal dan Hak Asasi Manusia, Komisi Nasional Hak Asasi Manusia, Jakarta, ELSAM,2007

Kaul,Hans Peter, Development at The International Criminal Court:Contruction Site for More Justice: The ICC Afther Two Year, April 2005 .

Human Right Watch, Genosida Kejahatan Perang dan Kejahatan Terhadap Kemanusiaan: Saripati Kasus Pelanggaran HAM berat dalam ICTR, Jilid I, Jakarta, Elsam, 2007

Human Right Watch, Genosida Kejahatan Perang dan Kejahatan Terhadap Kemanusiaan: Saripati Kasus Pelanggaran HAM berat dalam ICTY, Jilid II Jakarta, Elsam, 2007

Kelsen, Hans, General Theory of Law and State, Translated by Anders Wedberg, Russell\& Russell, New York, 1973.

Teori Hukum Murni,Penerjemah Somardi, Jakarta,Rindi Press, 1995.

, Hukum dan Logika, terjemahan Arief Sidharta, Bandung,Alumni, cet.3, 2006.

Nowak Manfred, Pengantar pada Rezim HAM Internasional,Penerjemah Sri Sulastini,Martinus Nijhoff Publishers.2003. 
Rhona K.M. Smith, Njal Hostmaelingen, ( et. al), Hukum Hak Asasi Manusia, Yogyakarta, PUSHAM UII, 2008.

Robertus Robet, Politik Hak Asasi Manusia dan Transisi di Indonesia, Jakarta Elsam, , 2008.

Romli Atmasasmita, Kapita Selekta Hukum Pidana Internasional, Jakarta Rajawali Press, 2007

, Hukum Pidana Internasional, Bag II, PT Hecca Mitra Utama, Jakarta, 2004.

, Pengantar Hukum Pidana Internasional, Jakarta,PT Refika Aditama, cet 32006.

Sudikno Mertokusumo, Penemuan Hukum, Liberty, Yogyakarta, cet 2, Juni 2001 , Hukum Organisasi internasional, Jakarta,UI Press, 1990.

Soerjono Soekanto, Teori yang murni tentang hukum, Bandung, Alumni, 1985.

Tim Elsam, Mahkamah Pidana Internasional : Statuta Roma, Hukum Acara, dan Unsur Unsur Kejahatan, , Jakarta.Elsam,2007

William Driscoll,Joseph Zompetti And Suzette W. Zompetti, The International Criminal Court : Global Politics and The Quest for Justice, The International Debate Education Association, New York, 2004.

Yudha Bhakti Ardhiwisastra, Penafsiran dan Konstruksi Hukum, Bandung, Alumni, 2008. , Hukum internasional, Bunga Rampai, Bandung,Alumni, 2003.

\section{Perundang-undangan :}

Statuta Roma

\section{Internet}

Papang Hidayat, Komisi Kebenaran dan Rekonsiliasi;Alternatif Penyelesaian Kejahatan HAM Masa Lalu?,www.kontras.org. 31 Desember 2010

Galuh Wandita, Kesempatan dalam Kesempitan:Beberapa catatan awal untuk mengusik impunitas yang telah terlembaga di Indonesia, www.syarikat.org, 27 Desember 2010

Margiyono, Pengadilan Khmer Merah Masih Hadapi Masalah, www.Vhrmedia.com. 20 des 2010

Yerry Niko Borang, Kamboja Gelar Pengadilan Kejahatan HAM, http://www.vhrmedia.net, 27 Desember 2010 